\title{
CAMA
}

Centre for Applied Macroeconomic Analysis

\section{Rent Extraction by Capitalists}

\section{CAMA Working Paper 20/2016 May 2016}

\section{Markus Brueckner}

Research School of Economics, ANU and

Centre for Applied Macroeconomic Analysis, ANU

\begin{abstract}
Rent extraction by capitalists is present if the capital income share exceeds the capital output elasticity. Based on a sample of 111 countries during the period 1970-2010, this paper provides estimates of the capital output elasticity and compares these to countries' capital income shares. Three findings arise: (i) for the average country in the sample, the capital income share significantly exceeds the capital output elasticity; (ii) the difference between the capital income share and the capital output elasticity has increased since the 1980s; (iii) in democracies the capital income share is not significantly different from the capital output elasticity.
\end{abstract}




\section{Keywords}

Capital output elasticity, capital income share, rent extraction.

\section{JEL Classification}

E0, O4

\section{Address for correspondence:}

(E) cama.admin@anu.edu.au

\section{ISSN 2206-0332}

The Centre for Applied Macroeconomic Analysis in the Crawford School of Public Policy has been established to build strong links between professional macroeconomists. It provides a forum for quality macroeconomic research and discussion of policy issues between academia, government and the private sector.

The Crawford School of Public Policy is the Australian National University's public policy school, serving and influencing Australia, Asia and the Pacific through advanced policy research, graduate and executive education, and policy impact. 


\title{
Rent Extraction by Capitalists
}

\author{
by \\ Markus Brueckner*
}

April 2016

\begin{abstract}
Rent extraction by capitalists is present if the capital income share exceeds the capital output elasticity. Based on a sample of 111 countries during the period 1970-2010, this paper provides estimates of the capital output elasticity and compares these to countries' capital income shares. Three findings arise: (i) for the average country in the sample, the capital income share significantly exceeds the capital output elasticity; (ii) the difference between the capital income share and the capital output elasticity has increased since the 1980s; (iii) in democracies the capital income share is not significantly different from the capital output elasticity.
\end{abstract}

Key words: Capital output elasticity, capital income share, rent extraction JEL codes: E0, O4

\footnotetext{
* Research School of Economics and Centre for Applied Macroeconomics, Australian National University. Contact email: markus.brueckner@anu.edu.au. I thank Alison Booth, Begona Dominguez, Chris Gibbs, Loukas Karabarbounis, Ian King, Brent Neiman, Ilan Noy, Jakob Madsen, Prasada Rao, and Brian Schmidt for useful comments on an earlier draft; comments received during seminar presentations at the University of Barcelona, Deakin University, Australian National University, Monash University, University of Vienna, University of Western Australia and the Workshop of the Australasian Macro Society are also very much appreciated.
} 


\section{Introduction}

An important dimension of income inequality is the share of income that accrues to the owners of capital (referred to as capitalists). In the presence of perfect competition the capital income share is equal to the capital output elasticity. However, if there is imperfect competition then the capital output elasticity will be different from the share of income that is paid out to capital owners: Capitalists are extracting rents when the capital income share exceeds the capital output elasticity. ${ }^{1}$ This paper addresses the question whether rent extraction by capitalists is a significant determinant of the cross-country time-series variation in the capital income share? Two interesting stylized facts in this regard are that capital income shares have increased for the majority of countries in recent decades, see Figure 1; and that the cross-country variation of the capital income share is substantial, see Figure 2.

Based on a panel of 111 countries during the 1970-2010 period, this paper estimates capital output elasticities and compares the estimates to capital income share data that are provided by the Penn World Table (Feenstra et al., 2013). Three main findings arise. The first main finding is that, on average, the capital income share significantly exceeds the capital output elasticity. The capital output elasticity for the average country in the sample is around 0.40 whereas the average capital income share is around 0.46. Statistical tests reject the hypothesis that the average capital income share is equal to the average capital output elasticity at the 1 percent significance level. Hence, for the average country in the sample there is evidence that during 1970-2010 capitalists extracted rents.

The paper's second finding is that the difference between the capital income share and the capital output elasticity has increased over time. For the period 1970-1979 the average difference

1 With the capital output elasticity, $\alpha$, I refer to the effect that a change in the natural logarithm of physical capital has on the change in the natural logarithm of GDP: i.e. $\alpha \equiv \mathrm{d} \ln (\mathrm{Y}) / \mathrm{d} \ln (\mathrm{K})=(\mathrm{dY} / \mathrm{dK})(\mathrm{Y} / \mathrm{K})$. If markets are competitive it holds that $\mathrm{dY} / \mathrm{dK}=\mathrm{r} \leftrightarrow \alpha=\mathrm{rK} / \mathrm{Y}$, i.e., the marginal benefit of capital accumulation (the marginal product of capital) is equal to the marginal cost (the rental rate). If capital owners extract rents, then the capital output elasticity is smaller than the capital income share, i.e. $\alpha<\mathrm{rK} / \mathrm{Y}$. The presence of positive physical capital externalities (see e.g. DeLong and Summers, 1992) implies that finding $\alpha<\mathrm{rK} / \mathrm{Y} \leftrightarrow \mathrm{rK} / \mathrm{Y}-\alpha>0$, is a lower bound of the extent to which capital owners extract rents. 
between the capital income share and the capital output elasticity is 5 percentage points while for the 1980-2010 period it is 7 percentage points. This 2 percentage points difference between the capital income share and the average capital output elasticity between the pre- and post-1980 period is significant at the 1 percent level. The increase over recent decades in the difference between the capital income share and the capital output elasticity is also present when splitting the sample into alternative sub-periods, e.g. pre- and post-1990 period and pre- and post-2000; or allowing for a (linear) trend in the capital income share and the capital output elasticity.

According to the widely-used Polity IV data, the average country in the sample is a nondemocracy. That is, the majority of countries are either an autocracy or an anocracy. About onethird of the countries in the sample are democracies, i.e. in these countries there exist tight political constraints and significant political competition. When the sample is restricted to non-democracies, the capital income share continues to significantly exceed the capital output elasticity. However, in democracies the hypothesis that the capital income share is equal to the capital output elasticity cannot be rejected at the conventional significance levels. The difference between the capital income share and the capital output elasticity is around ten percentage points in non-democracies; in democracies this difference is less than one percentage point.

As argued in Acemoglu and Robinson (2012) non-inclusive political institutions go hand in hand with non-inclusive economic institutions. In countries where a broad cross-section of people, i.e. the workers, have no voting rights or where there is no political competition the state can pass laws that are in the interests of a narrow elite. This elite may be directly linked to the state, e.g. through party membership; or indirectly, through e.g. financially sponsoring the autocratic regime. It is important to note that worker expropriation is not limited to developing and emerging market countries that are non-democratic; it also exists in high-income oil exporting countries located in the Middle East (e.g. Qatar) and financial hubs such as Singapore and Hong Kong. ${ }^{2}$

2 For example, the unusually high death toll of workers employed in building infrastructure for the World Cup that is to be hosted in Qatar in 2022 is an indication of worker expropriation in that country. In 1970 the capital income share in Qatar was 76 percent, in 2010 it was 82 percent. 
In non-democratic countries the elite is backed by political power (that allows it to amend the law in its interest and exercise control over the military and police); it owns the capital stock; and sets wages that are below the marginal product of labor. A useful way to think of non-inclusive economic institutions in this context is to imagine a firm that acts as a monopsonist. The monopsonistic firm sets a (real) wage that is below workers' marginal product. Non-democratic political institutions ensure that the firm can set such wages: in non-democracies workers have no effective means to protest and induce an increase in their real wage. This is because, in nondemocracies, the political rulers can pass laws that prevent demonstrations of workers; and, in case demonstrations do occur, the police and military can be used by the political rulers to counteract and dissolve an uprising of the workers.

The finding that there exists significant rent extraction by capitalists in non-democracies, but not in democracies, is related to Rodrik (1999). Rodrik documents that democracies pay higher wages, and that the labor income share is higher in democracies. However, without estimates of the capital output elasticity, one cannot infer from the results in Rodrik (1999) that a lower labor income share in non-democracies is due to rent extraction by capitalists.

Karabarbounis and Neiman (2014a) argue that the decline of the relative price of investment is an important driver of the decline of the labor income share since the $1980 \mathrm{~s} .{ }^{3}$ The authors find that about half of the variation in the labor income share is due to the decline in the relative price of capital. Karabarbounis and Neiman account in their empirical analysis for markups, i.e. extraction of rents in the product market. Rent extraction in the goods market is distinct from rent extraction by capitalists. Rent extraction in the goods market implies that firms make profits, and it is unclear how these profits will be distributed between capital and labor. Another key difference between this paper and Karabarbounis and Neiman is that the authors do not distinguish in their analysis between

3 The result in Karabarbounis and Neiman (2014a) critically depends on the elasticity of substitution between labor and capital to exceed unity. As noted in, for example, Acemoglu and Robinson (2014), there is some controversy in the literature with regard to whether the elasticity of substitution is below, equal to, or above unity. Acemoglu (2003) examines the effect of labor- and capital-augmenting technological change on the labor income share, using an elasticity of substitution between capital and labor below unity. Chirinko and Mallick (2014) find that the long-run elasticity of substitution between capital and labor is significantly below unity. 
democracies and non-democracies.

Literature that uses industry or firm level data has typically found evidence for markups in product markets that are significantly different from zero. ${ }^{4}$ In an imperfectly competitive product market, a monopolistic firm sets price above marginal cost. The first order conditions of the basic maximization framework imply that the value marginal product of labor is equal to the wage times a markup; and the value marginal product of capital is equal to the rental rate times a markup. Detecting evidence of significant markups does not imply, however, that capitalists are extracting rents: if firms charge markups and make profits, then it is unclear what happens with firms' profits (in a dynamic setting). If firms' profits are paid out to capital owners, then this will have a positive effect on the capital income share; on the other hand, if workers have bargaining power, say, because of the presence of unions, then part of the rents that firms extract from consumers in the goods market will be paid out to workers. Thus, for answering the question whether, and to what extent, variation in the capital income share is due to rent extraction by capitalists one needs to consider the difference between the capital income share and the capital output elasticity (and not the difference between price and marginal cost).

The rest of the paper is organized as follows. Section 2 discusses the data. Section 3 explains the estimation strategy. Section 4 presents the main results. Section 5 concludes.

\section{Data}

Capital and Other Macro Variables. Data on macroeconomic variables -- real GDP, physical capital, the number of workers, average hours worked, human capital, total factor productivity, the labor income share, the relative price of investment -- are from the Penn World Table, version 8.0 (Feenstra et al., 2013). The availability of this data determines the sample size in the regressions. For a list of countries in the sample see Appendix Table 1. Appendix Table 2 provides descriptive statistics. Figure 3 (4) provides a scatter plot of the unconditional relationship between 5-year

4 See, for example, Hall (1988) for an early contribution. 
changes in output (per worker) and capital (per worker) for the sample at hand.

The capital income share is constructed as 1 minus the labor income share. Data on the labor share are from the PWT, version 8.0; in particular, data on PWT's "best estimate" of the labor share are used to compute the capital income share. PWT is careful in accounting for labor income from self-employment. As noted in Gollin (2002), neglecting labor income of self-employed workers leads to an understatement of the labor income share (and hence an overstatement of the capital income share). As described in Inklaar and Timmer (2013), PWT 8.0 use data on mixed income available for around 60 countries - to account for labor income of self-employed workers. In the adjustment, PWT assumes that the labor share for mixed income is the same as for the rest of the economy. ${ }^{5}$ For countries where no data on mixed income are available PWT makes adjustments to a naive labor income share by using information on the agricultural value added share. For countries where the adjusted labor income share exceeds 0.7, the PWT assumes that the naive labor income share already includes an imputation for self-employed labor income.

PWT data do not account for non-produced assets, such as land and subsoil assets. Inklaar and Timmer (2013) note that incorporating non-produced assets would imply changes to both capital and GDP; and that measuring the stock of non-produced assets and their values is difficult, even for a single country. ${ }^{6}$

For the construction of the capital stock the PWT uses the perpetual inventory method; investment is distinguished by asset class and depreciation rates vary across countries and time. The PWT data are based on the System of National Accounts (1993). According to the System of National Accounts (1993, page 7): "Changes in the values of naturally occurring assets owned by institutional units between one balance sheet and the next are recorded in the accumulation accounts of the System. For example, the depletion of a natural asset as a result of its use in production is recorded in the other changes in volume of assets account, together with losses of fixed assets due

5 Mixed income is the sum of capital and labor income of self-employed workers.

6 See, e.g. Caselli (2005) for an approach that takes into account land. 
to their destruction by natural disasters (floods, earthquakes, etc.)." More specifically, in K7 of Table 2.1, Account III.3.1, the System of National Accounts (1993) records catastrophic losses in both non-financial and financial assets. ${ }^{7}$

Political Institutions. Data on political institutions are from the Polity IV (2014) database. The Polity IV database provides a so-called polity2 score that is based on political scientists' expert evaluations. Political scientists evaluate countries' political competition, political constraints and executive recruitment. Based on scores given by political scientists on countries' political competition, political constraints, and executive recruitment a combined revised polity 2 score is produced by Polity IV that ranges between -10 and 10 . Higher values of the polity 2 score represent stronger democratic institutions. Based on the polity2 score, countries are classified as democracies if their polity2 score exceeds 6; otherwise they are classified as non-democracies. According to Polity IV (2014), non-democracies can further be separated into autocracies and anocracies. Autocracies are countries with a polity2 score below -6; the remaining countries that are neither democracies nor autocracies are anocracies.

Panel A of Figure 5 shows a scatter plot of the relationship between countries' average capital income shares and polity 2 scores. In Panel B of Figure 5 variations in the polity 2 scores are used which are predicted by countries' distance from the equator. ${ }^{8}$ Both panels of Figure 5 show a negative relationship that is statistically significant at the 5 percent level. The negative relationship

7 With regard to the depreciation rate, the SNA (1993, page 184) states that: "Losses of fixed assets due to normal accidental damage are also included under consumption of fixed capital; that is, damage caused to assets used in production resulting from their exposure to the risk of fires, storms, accidents due to human errors, etc. When these kinds of accidents occur with predictable regularity they are taken into account in calculating the average service lives of the goods in question. At the level of the economy as a whole, the actual normal accidental damage within a given accounting period may be expected to be equal, or close, to the average. However, for an individual unit, or group of units, any difference between the average and the actual normal accidental damage within a given period is recorded in the other changes in volume of assets account. On the other hand, losses due to war or to major natural disasters which occur very infrequently - major earthquakes, volcanic eruptions, tidal waves, exceptionally severe hurricanes, etc. - are not included under consumption of fixed capital. There is no reason for such losses to be charged in the production account as costs of production. The values of the assets lost in these ways are recorded in the other changes in volume of assets account."

8 Hall and Jones (1999) used distance to the equator as an instrument for institutions when examining the effect of institutions on output. Distance to the equator captures a feature of countries' institutions that is permanent. Further, as shown in Acemoglu et al. (2001), distance to the equator has no direct effects on output. 
confirms the previous finding in Rodrik (1999) that the capital income share is significantly lower in democracies. However, without information on the capital output elasticity one cannot conclude that the lower capital income share is due to the absence (lower degree) of rent extraction by capitalists in democracies. This is because the lower capital income shares in democracies could simply be due to a lower capital output elasticity.

\section{Estimation Framework}

The estimating equation relates the change in the natural logarithm of real output, $\Delta \ln (\mathrm{Y})$, to changes in the natural logarithms of physical capital, $\Delta \ln (\mathrm{K})$, and the number of workers, $\Delta \ln (\mathrm{L})$ :

$$
\Delta \ln \left(\mathrm{Y}_{\mathrm{it}}\right)=\mathrm{a}_{\mathrm{i}}+\mathrm{b}_{\mathrm{tc}}+\alpha \Delta \ln \left(\mathrm{K}_{\mathrm{it}}\right)+\beta \Delta \ln \left(\mathrm{L}_{\mathrm{it}}\right)+\mathrm{e}_{\mathrm{it}}
$$

where $a_{i}$ are country fixed effects; $b_{t c}$ are continent-specific time fixed effects; and $e_{i t}$ is an error term. The capital-output elasticity is given by the coefficient $\alpha$.

Equation (11) uses the first-differences of the series in order to avoid spurious regression results that can arise from non-stationarity in the levels of the series. Appendix Table 3 shows that panel unit root tests do not reject the null of non-stationarity in the level of the series for GDP, capital, employment, and TFP. The panel unit root tests reject the null of non-stationarity in the first differences of the series at the 1 percent significance level. For the incidence of earthquakes, the panel unit root tests reject the null of non-stationarity in the levels and the first differences.

Equation (11) is estimated based on 5-year non-overlapping panel data. 5-year nonoverlapping panel data smooth business-cycle fluctuations that are present in annual data. As a robustness check, the paper will present estimates that are based on 10-year non-overlapping panel data and annual panel data.

The 5-year non-overlapping panel comprises 111 countries and spans the period 1970-2010. It is an unbalanced panel that provides a total number of 792 observations -- the largest number of observations given the available macroeconomic data. As a robustness check, estimates will be 
presented that are based on a balanced panel comprising 62 countries during the 1970-2010 period.

\section{Results}

Panel A of Table 4 presents two-stage least squares estimates of the capital output elasticity. In columns (1)-(3) the dependent variable is the change in the natural logarithm of the output-worker ratio; the endogenous variable is the change in the natural logarithm of the capital-worker ratio. In these columns the estimated elasticity coefficient on the capital-worker ratio gives an estimate of the capital-output elasticity under the restriction of constant returns in capital and labor. In columns (4)-(6) this restriction is relaxed by using as dependent variable the change in the natural logarithm of output; the endogenous variable is the change in the natural logarithm of capital.

The instrumental variables regressions yield a capital output elasticity that is positive and significantly different from zero at the 1 percent level. When country and continent-specific time fixed effects are included, see columns (3) and (6), the second-stage coefficient on the natural logarithm of capital (capital per worker) is around $0.36(0.40)$. This second-stage coefficient suggests that on average a one percent increase in capital (capital per worker) increases output (output per worker) by around $0.36(0.40)$ percent. Further, it is noteworthy that column (6) of Table 4 shows that the sum of the elasticity response of output to capital and the elasticity response of output to labor is around 0.9. Since human capital is omitted from the regressions, these estimates are consistent with constant returns to scale and a return to human capital accumulation of around 10 percent. $^{9}$

In terms of first-stage fit the quality of the 2SLS estimates is reasonable. Robust to the inclusion of country fixed effects, time fixed effects, and continent-specific time fixed effects the Kleibergen Paap F-statistic is in excess of 10. This is true regardless of whether the endogenous variable is the growth rate of capital or the growth rate of the capital-worker ratio.

9 Caselli and Ciccone (2013) provide estimates of Mincerian returns that are around ten percent for the average country. 
The exclusion restriction underlying the instrumental variables regressions is that the change in the incidence of earthquakes has no significant effects on output growth beyond the effect that the change in the incidence of earthquakes has on capital growth. Table 3 documented that the change in the incidence of earthquakes has no significant effects on the standard variables that are part of the production function. In order to provide additional results showing that there is no evidence for the exclusion restriction to be violated, Appendix Table 6 provides two-stage least squares estimates that use the change in the incidence of floods and storms as additional instruments. The overidentified instrumental variables regressions enable to compute the Hansen $\mathrm{J}$ test on the null that the instruments are jointly uncorrelated with the second-stage error term. As can be seen, the $\mathrm{p}$-value of the Hansen $\mathrm{J}$ test is always in excess of 0.1 . Hence, the Hansen $\mathrm{J}$ test does not reject the null that the instruments are valid.

Appendix Table 7 reports the direct and unconditional effects that the change in the incidence of earthquakes has on the growth rate of GDP per worker. Columns (1)-(3) of Appendix Table 7 show that, conditional on growth of capital per worker the change in the incidence of earthquakes has no significant effect on the growth rate of GDP per worker. ${ }^{10}$ This suggests that there is no systematic direct effect of the change in the incidence of earthquakes on GDP per worker growth. For comparison to the conditional effect, columns (4)-(6) of Appendix Table 6 report the unconditional effect (i.e. the reduced form). The change in the incidence of earthquakes has a significant negative contemporaneous effect on the growth rate of GDP per worker. This is consistent with literature that has documented a significant negative effect of natural disasters on output (Noy, 2009; Strobl, 2012). What is new is that the average effect of the incidence of earthquakes on output per worker goes exclusively through capital per worker.

Panel B of Table 4 reports least squares estimates. These are quantitatively of similar size as

10 Capital per worker growth is instrumented in these regressions with the change in the incidence of storms and floods. Appendix Table 8 documents that the change in the incidence of storms and floods have no significant effects on the growth rates of population, workers, average hours worked, average years of schooling, and total factor productivity. 
the 2SLS estimates. For example, when country fixed effects and continent-specific time fixed effects are included as controls the least squares coefficient on the natural logarithm of capital (capital per worker) is $0.40(0.41)$. For none of the specifications does the Hausman test reject the hypothesis that the 2SLS coefficient is equal to the LS coefficient (p-value above 0.1).

The estimates imply that, for the average country in the sample, the difference between the capital income share and the capital output elasticity is positive. ${ }^{11}$ Panel $\mathrm{C}$ of Table 4 reports the difference between the capital output elasticity and the capital income share. Quantitatively, this difference is sizable. For example, the estimates in column (6) of Table 4 imply that, for the average country in the sample, the capital income share is about 7 percentage points above the capital output elasticity. Statistically, this value is significantly different from zero at the 1 percent significance level.

Karabarbounis and Neiman (2014a) argue that variations in the relative price of investment are a significant driver of variations in the capital income share. Regressing the capital income share on the relative price of investment in a fixed effects model yields a coefficient (standard error) of $-0.023(0.006)$ for the sample at hand. This suggests that a lower relative price of investment leads to a significantly higher capital income share, thus consistent with Karabarbounis and Neiman (2014a).

The estimated relationship $r K / Y=-0.023 P^{I} / P^{C}+e$ can be used to compute a capital income share, $e$, that is adjusted for the effect that the relative price of investment has on the capital income share. Using the adjusted capital income share, one can compute the difference between the capital output elasticity and the capital income share that is not due to variation in the relative price of investment. This difference is negative and, in absolute value, larger than the difference between the capital output elasticity and the unadjusted capital income share. For example, the estimates in column (6) imply that the difference between the adjusted capital income share and the capital

11 Appendix Tables 9-12 show that the same result arises when using a balanced panel that comprises 62 countries during 1970-2010; using 10-year non-overlapping panel data; using annual panel data; or controlling for human capital. 
output elasticity is around 9 percentage points. Hence, adjusting the capital income share for the effect that variations in the relative price of investment have on this variable provides stronger evidence for rent extraction by capitalists than using an unadjusted measure of the capital income share.

Table 5 shows that the difference between the capital income share and the capital output elasticity has increased in recent decades. ${ }^{12}$ This can be seen, for example, by looking at columns (1) and (4) of Table 5. These columns report estimates from an econometric model that includes an interaction term between the capital output elasticity and an indicator variable that is unity for the post-1980 period. Estimation of this model yields a coefficient on the natural logarithm of capital (capital per worker) of around $0.40(0.41)$; the coefficient on the post-1980 interaction term is quantitatively small and statistically insignificant regardless of whether the right-hand-side variable is the natural logarithm of capital or capital per worker. This suggests that the capital output elasticity is not significantly different for the post-1980 period. In order to compute the difference between the capital output elasticity and the capital income share for the sub-periods of interest, one needs information on the capital income share for these sub-periods. The average capital income share for the period $1970-1979$ is 0.45 ; for the period $1980-2010$ it is 0.47 . These values, combined with the estimates in Table 5, imply that the difference between the capital income share and the capital output elasticity is about two percentage points higher for the post-1980 period. ${ }^{13}$

The capital income share is significantly larger than the capital output elasticity in nondemocracies, but not in democracies. This is shown in Table $6 .{ }^{14}$ The table reports estimates of an econometric model that includes an interaction term between capital and an indicator variable that is unity if countries are a democracy. Columns (1) and (3) report estimates that use a democracy

12 The same result emerges when adjusting the capital income share for the effect that variations in the relative price of investment have on this variable (estimates not shown).

13 Appendix Table 13 reports estimates from a model that includes interaction terms between the right-hand side variables and a linear time trend. The results are similar to Table 5: the difference between the capital income share and the capital output elasticity has increased throughout the 1970-2010 period.

14 The number of observations in Table 6 is slightly lower than in the previous tables because Polity IV provides no data on the polity2 score for Barbados, Hong Kong, Iceland, Macao, and Malta. 
indicator variable based on the actual polity2 score. Columns (2) and (4) report estimates that use a democracy indicator variable based on the polity 2 score predicted by distance from the equator. The difference between the capital income share and the capital output elasticity is positive and significantly different from zero in non-democracies; in democracies it is quantitatively small and statistically indistinguishable from zero. For example, according to the estimates in column (3) of Table 6 the difference between the capital income share and the capital output elasticity is 10 percentage points in non-democracies (standard error 2 percentage points); in democracies it is less than 1 percentage point (standard error 2 percentage points). The hypothesis that the difference between the capital income share and the capital output elasticity is the same in democracies and non-democracies can be rejected at the 1 percent significance level.

Table 7 shows that the same message arises as in Table 6 when restricting the sample to post-1980 (Panel A) and post-1990 (Panel B). In non-democracies the difference between the capital income share and the capital output elasticity is around 10 percentage points for the post1980 period and around 9 percentage points for the post-1990 period. For the group of nondemocratic countries one can reject the null hypothesis that the difference between the capital income share and the capital output elasticity is equal to zero at the 1 percent significance level. On the other hand, in democracies, the difference between the capital income share and the capital output elasticity is quantitatively small and statistically indistinguishable from zero. Further, one can reject the hypothesis that the difference between the capital income share and the capital output elasticity is the same in democracies and non-democracies at the 1 percent significance level. This is true for the post-1980 and the post-1990 period.

Distinguishing between autocracies and anocracies within the group of non-democracies, the estimates reported in Table 8 show that rent extraction by capitalists is present in both anocracies and autocracies. Panel A of Table 8 reports estimation results for anocracies and Panel B of Table 8 reports estimation results for autocracies. Table 8 shows that the difference between the 
capital income share and the capital output elasticity is positive and significantly different from zero at the 1 percent significance level in both anocracies and autocracies. Quantitatively, the difference between the capital income share and the capital output elasticity is sizable in both types of political regimes. For example, column (6) of Table 8 shows that the difference between the capital income share and the capital output elasticity is around 9 percentage points in anocracies and around 10 percentage points in autocracies. Hence, the difference between the capital income share and the capital output elasticity is somewhat larger in autocracies than in anocracies. Given standard errors, one cannot however reject the hypothesis that the difference between the capital income share and the capital output elasticity is the same in autocracies and anocracies ( $p$-value above 0.1 ).

\section{Conclusion}

Figure 1 showed that the capital income share has increased in recent decades; and Figure 5 showed that the capital income share is significantly lower in democracies. Both two stylized facts are well recognized in the literature (e.g. Piketty, 2013; Rodrik, 1999). An important question that arises from these stylized facts is whether, and to what extent, the observed time-series and cross-country variation in the capital income share is due to rent extraction by capitalists?

Rent extraction by capitalists is present if the capital income share exceeds the capital output elasticity. This paper used publicly available data from the Penn World Table (Feenstra et al., 2013) to estimate the difference between the capital output elasticity and the capital income share. Based on a rigorous panel data model that included country and continent-specific time fixed effects, the paper obtained three main results: (i) for the average country in the sample, the capital income share significantly exceeds the capital output elasticity; (ii) the difference between the capital income share and the capital output elasticity has increased since the 1980s; (iii) in democracies the capital income share is not significantly different from the capital output elasticity. The last result is consistent with the view that inclusive political institutions support inclusive economic institutions 
(Acemoglu and Robinson, 2012). The finding suggests that rent extraction by capitalists is not a significant driver of the increase of the capital income share in democracies. ${ }^{15}$

The results in this paper have nothing to say about the role of education (human capital) and the widening of the wage gap between high-skilled and low-skilled workers. In particular, the analysis does not provide an answer to the question of whether it is rent extraction that is driving the widening in the wage gap between high-skilled and low-skilled workers. The distribution of labor's share in income between different types of workers is an important avenue of research, and it is beyond the scope of the current paper. Future research that seeks to answer the question of whether rent extraction by high-skilled workers has been a significant contributor to the rise in labor income inequalities, and whether rent extraction by high- skilled workers is determined by crosscountry differences in political institutions, could pursue a similar line of research to the one taken in this paper.

15 One explanation for the increase in the capital income share in democracies is the decline in the relative price of investment (Karabarbounis and Neiman, 2014a). 


\section{References}

Acemoglu, D., S. Johnson, and J. Robinson (2001). "The Colonial Origins of Comparative Development: An Empirical Investigation." American Economic Review 91: 1369-1401.

Acemoglu, D. (2003). "Labor and Capital-Augmenting Technical Change." Journal of the European Economic Association 1: 1-37.

Acemoglu, D. and J. Robinson (2012). Why Nations Fail: The Origins of Power, Prosperity, and Poverty. Crown Business.

Acemoglu, D. and J. Robinson (2015). "The Rise and Decline of General Laws of Capitalism." Journal of Economic Perspectives, forthcoming.

Caselli, F. (2005). "Accounting for cross-country income differences" in Phillipe Aghion and Steven N. Durlauf (eds.) Handbook of Economic Growth, Volume 1A, Elsevier: 679-741.

Caselli, F. and A. Ciccone (2013). "The Contribution of Schooling in Development Accounting: Results from a Nonparametric Upper Bound." Journal of Development Economics 104: 199211.

Chirinko, R. and D. Mallick (2014). "The Substitution Elasticity, Factor Shares, Long-Run Growth, and the Low-Frequency Panel Model." Cesifo WP 4895.

DeLong, B. and L. Summers (1992). "Equipment Investment and Economic Growth." Quarterly Journal of Economics 106: 445-502.

Feenstra, R., R. Inklaar, and M. Timmer (2013). "The Next Generation of the Penn World Table." available for download at www.ggdc.net/pwt.

Gollin, D. (2002). "Getting Income Shares Right." Journal of Political Economy 110: 458-474.

Hall, R. (1988). "The Relation between Price and Marginal Cost in U.S. Industry." Journal of Political Economy 96: 921-947.

Hall, R. And C. Jones (1999). "Why Do Some Countries Produce So Much More Output Per Worker Than Others?" Quarterly Journal of Economics 114: 83-116.

Im, K., Pesaran, H., and Y. Shin (2003). "Testing for Unit Roots in Heterogeneous Panels." Journal of Econometrics 115: 53-74.

Inklaar, R. and M. Timmer (2013). "Capital, labor and TFP in PWT 8.0." University of Groningen, mimeo.

Jones, C. (2005). "The Shape of Production Functions and the Direction of Technological Changes." Quarterly Journal of Economics 120: 517-549.

Karabarbounis, L. and B. Neiman (2014a). "The Global Decline of the Labor Share." Quarterly Journal of Economics 129: 61-103.

Karabarbounis, L. and B. Neiman (2014b). "Capital Depreciation and Declining Labor Shares Around the World." NBER WP 20606.

Polity IV (2014). "Political Regime Characteristics and Transitions, 1800-2014." Online database available for download at http://www.systemicpeace.org/.

Rodrik, D. (1999). "Democracies Pay Higher Wages." Quarterly Journal of Economics 114: 707738.

Staiger, D. and J. Stock (1997). "Instrumental Variables Regression With Weak Instruments." Econometrica 65: 557-586.

System of National Accounts (1993). Description file downloaded from http://unstats.un.org/unsd/nationalaccount/docs/1993sna.pdf.

WDI (2013). World Development Indicators. Available at http://data.worldbank.org/indicator

Wooldridge, J. (2002). Econometric Analysis of Cross Section and Panel Data. Cambridge, Mass.: MIT Press. 
Figure 1. The Capital Income Share 1970-2010

(Source: Penn World Table; Polity IV)

Panel A: Average Across 111 Countries

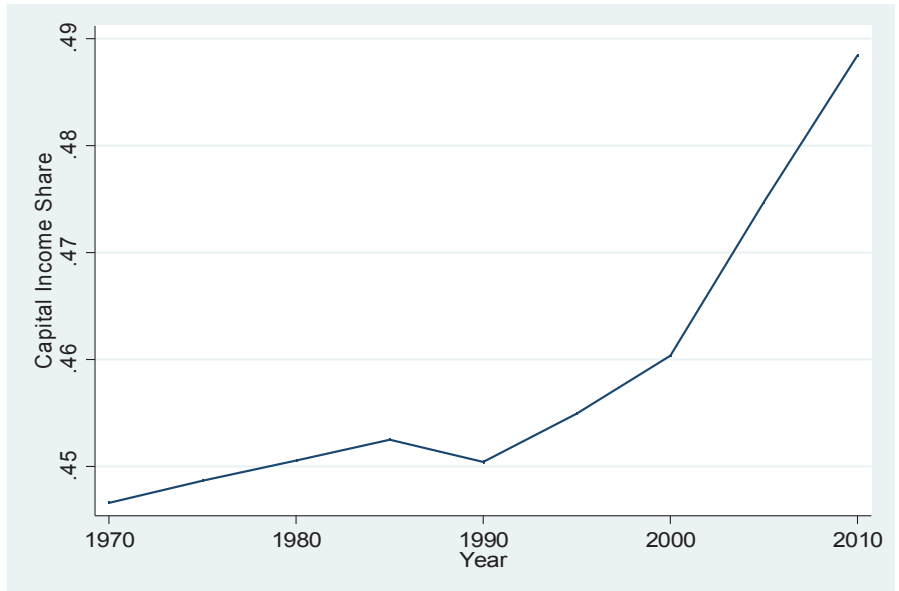

Panel B: Democracies

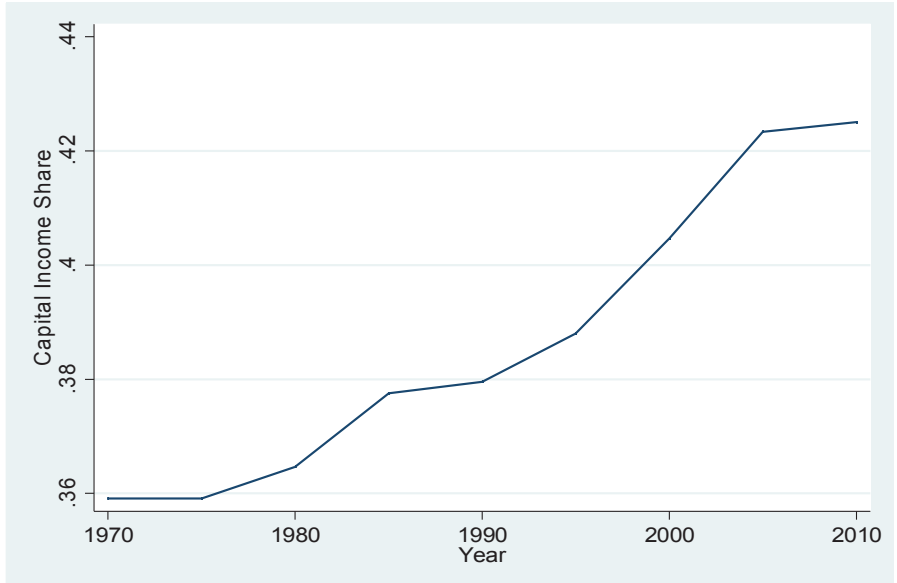

Panel C: Non-Democracies

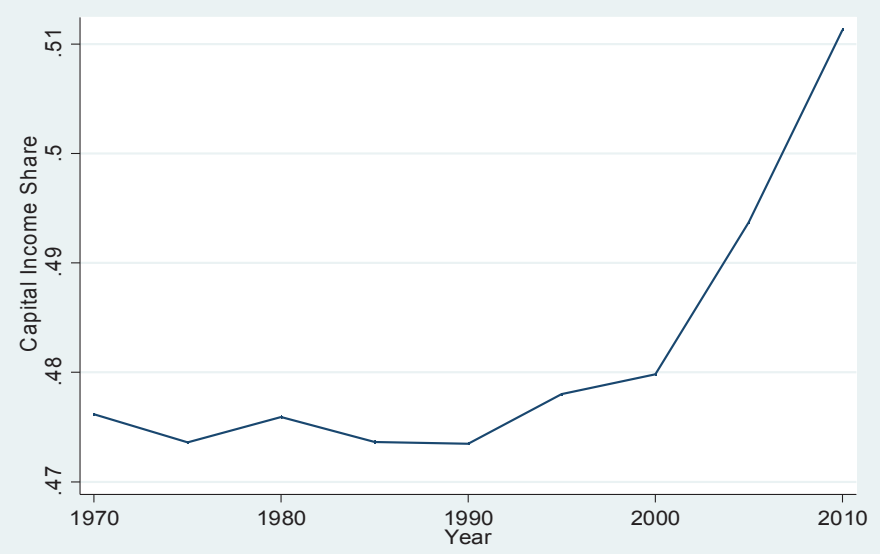


Figure 2. Distribution of Capital Income Share (Source: Penn World Table)

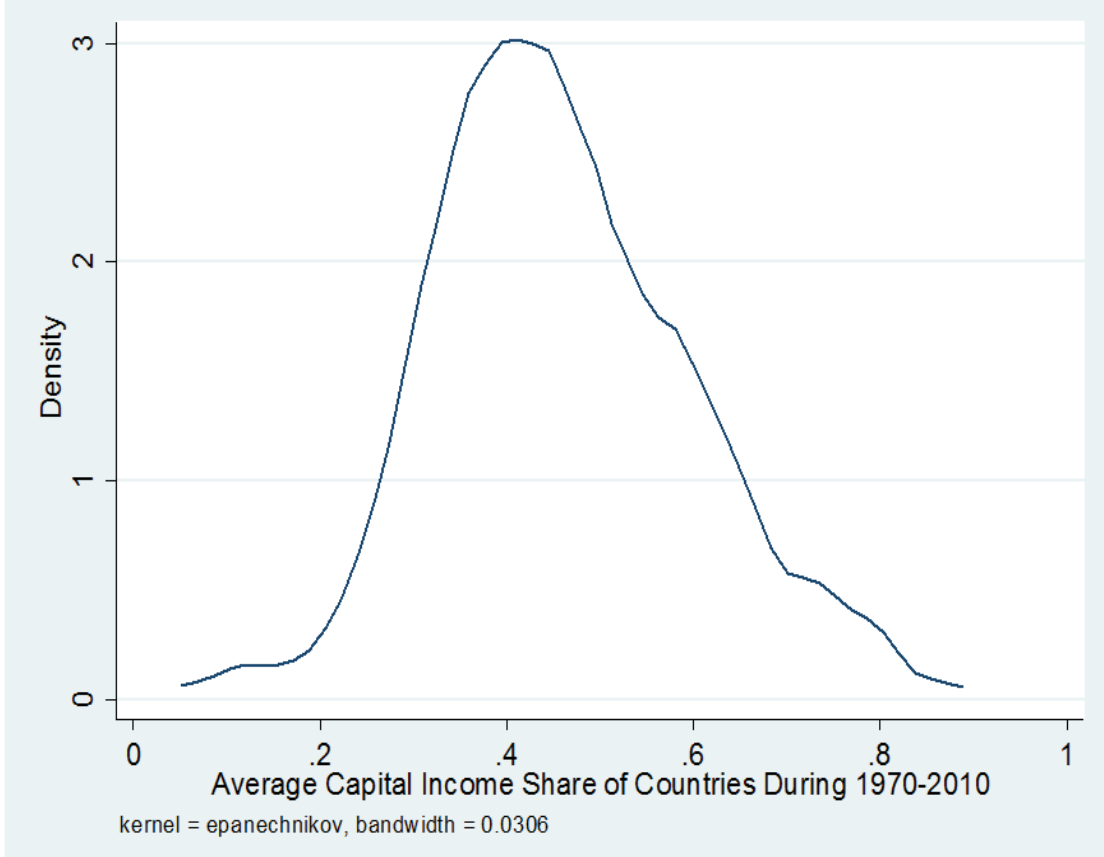


Figure 3. Scatter Plot of Changes in Capital Per Worker and Output per Worker

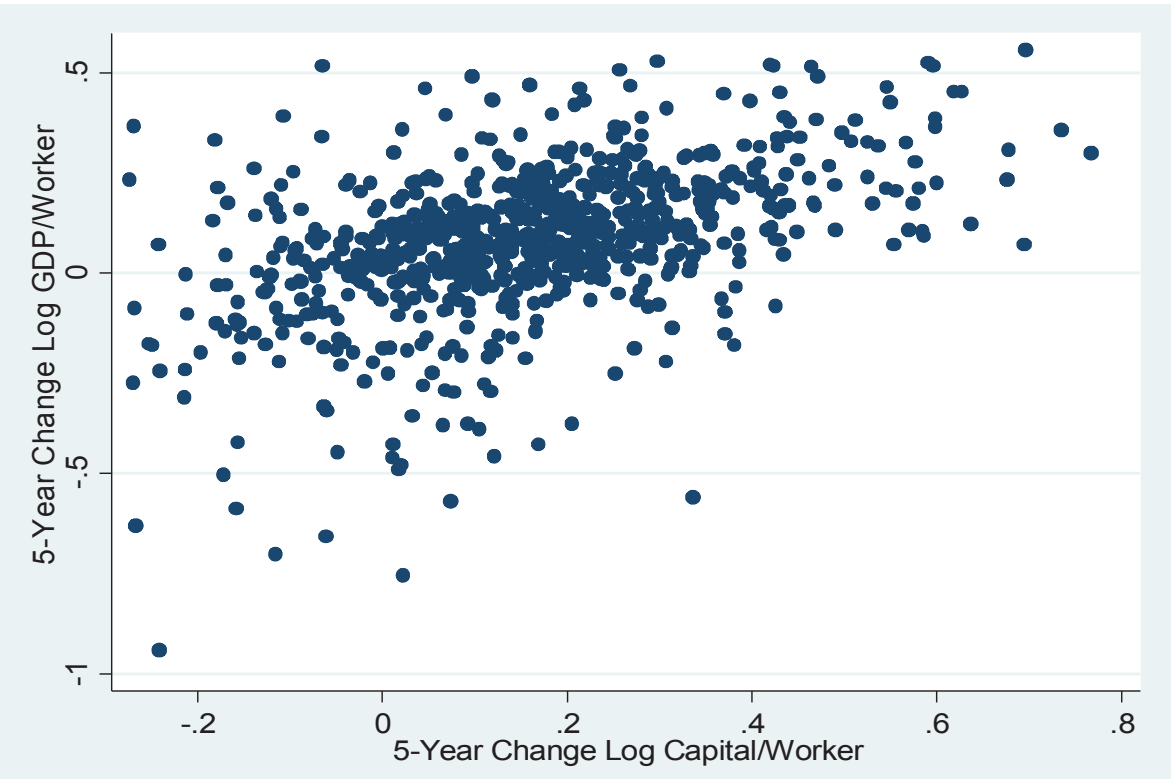

Figure 4. Scatter Plot of Changes in Capital and Output

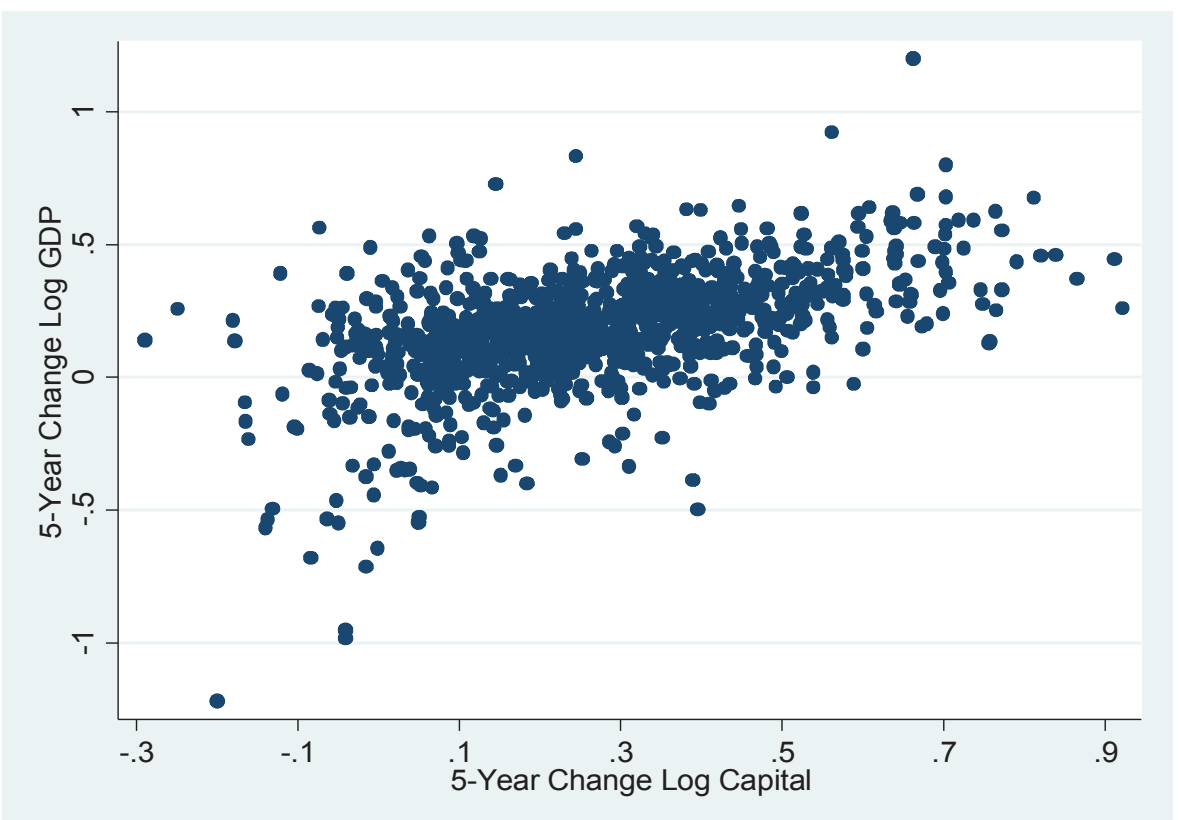


Figure 5. Political Institutions and the Capital Income Share

Panel A: Average Polity2 Score

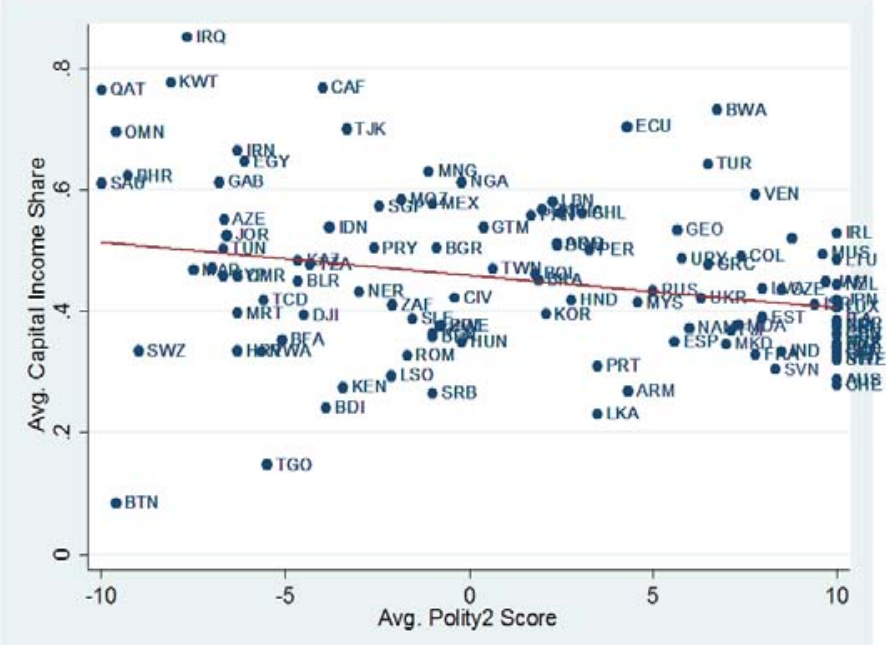

Panel B: Average Polity2 Score Predicted by Absolute Latitude

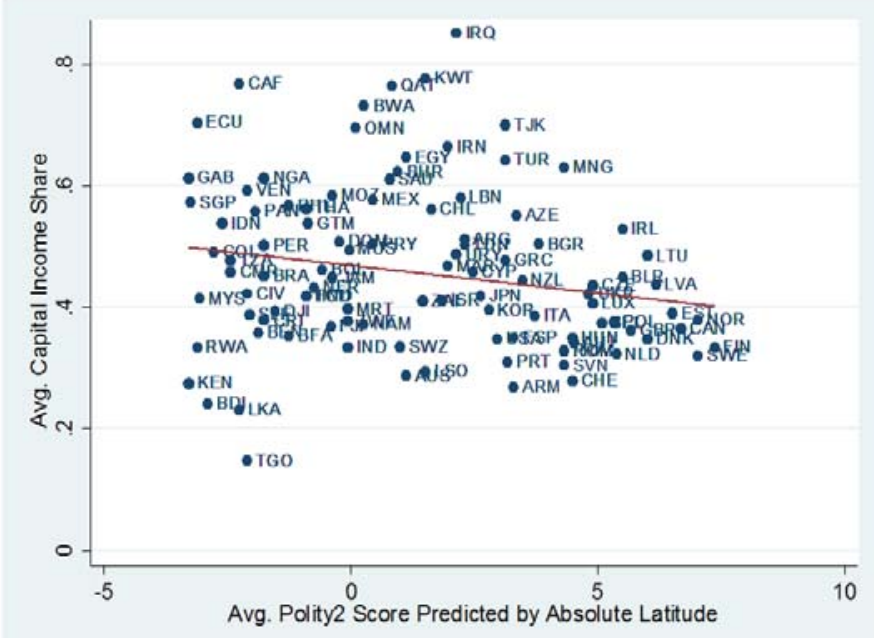


Table 1. Rent Extraction by Capitalists

(Unbalanced Panel)

\begin{tabular}{|c|c|c|c|c|c|c|}
\hline \multirow[t]{2}{*}{ Dependent Variable is: } & \multicolumn{3}{|c|}{$\Delta \ln (\mathrm{Y} / \mathrm{L})$} & \multicolumn{3}{|c|}{$\Delta \ln (Y)$} \\
\hline & $(1)$ & (2) & (3) & (4) & $(5)$ & $(6)$ \\
\hline$\Delta \ln (\mathrm{K} / \mathrm{L})$ & $\begin{array}{c}0.36^{* * * *} \\
(0.02)\end{array}$ & $\begin{array}{c}0.42^{* * * *} \\
(0.01)\end{array}$ & $\begin{array}{c}0.42 * * * \\
(0.01)\end{array}$ & & & \\
\hline$\Delta \ln (\mathrm{K})$ & & & & $\begin{array}{c}0.34 * * * \\
(0.02)\end{array}$ & $\begin{array}{c}0.41 * * * \\
(0.01)\end{array}$ & $\begin{array}{c}0.40 * * * \\
(0.02)\end{array}$ \\
\hline \multirow[t]{2}{*}{$\Delta \ln (\mathrm{L})$} & & & & $\begin{array}{c}0.48 * * * \\
(0.03)\end{array}$ & $\begin{array}{c}0.52 * * * \\
(0.02)\end{array}$ & $\begin{array}{c}0.50 * * * \\
(0.03)\end{array}$ \\
\hline & \multicolumn{6}{|c|}{ Difference Between Capital Output Elasticity and Capital Income Share } \\
\hline$\alpha-\mathrm{rK} / \mathrm{Y}$ & $\begin{array}{c}-0.11 * * * \\
(0.02)\end{array}$ & $\begin{array}{c}-0.04 * * * \\
(0.01)\end{array}$ & $\begin{array}{c}-0.05 * * * \\
(0.01)\end{array}$ & $\begin{array}{c}-0.13 * * * \\
(0.02)\end{array}$ & $\begin{array}{c}-0.05 * * * \\
(0.01)\end{array}$ & $\begin{array}{c}-0.06^{* * *} * \\
(0.02)\end{array}$ \\
\hline Country FE & Yes & Yes & Yes & Yes & Yes & Yes \\
\hline Time FE & No & Yes & Yes & No & Yes & Yes \\
\hline Time FE $*$ Continent FE & No & No & Yes & No & No & Yes \\
\hline Observations & 792 & 792 & 792 & 792 & 792 & 792 \\
\hline Countries & 111 & 111 & 111 & 111 & 111 & 111 \\
\hline
\end{tabular}

Note: The method of estimation is least squares. Huber robust standard errors (shown in parentheses) are clustered at the country level. *Significantly different from zero at the 10 percent significance level, $* * 5$ percent significance level, ${ }^{* * *} 1$ percent significance level. 
Table 2. Rent Extraction by Capitalists

(Balanced Panel)

\begin{tabular}{|c|c|c|c|c|c|c|}
\hline \multirow[t]{2}{*}{ Dependent Variable is: } & \multicolumn{3}{|c|}{$\Delta \ln (\mathrm{Y} / \mathrm{L})$} & \multicolumn{3}{|c|}{$\Delta \ln (Y)$} \\
\hline & (1) & (2) & (3) & (4) & (5) & (6) \\
\hline$\Delta \ln (\mathrm{K} / \mathrm{L})$ & $\begin{array}{c}0.31 * * * \\
(0.02)\end{array}$ & $\begin{array}{c}0.41 * * * \\
(0.01)\end{array}$ & $\begin{array}{c}0.41 * * * \\
(0.01)\end{array}$ & & & \\
\hline$\Delta \ln (\mathrm{K})$ & & & & $\begin{array}{c}0.30^{* * *} \\
(0.03)\end{array}$ & $\begin{array}{c}0.41 * * * \\
(0.02)\end{array}$ & $\begin{array}{c}0.41 * * * \\
(0.01)\end{array}$ \\
\hline \multirow[t]{2}{*}{$\Delta \ln (\mathrm{L})$} & & & & $\begin{array}{c}0.61 * * * \\
(0.04)\end{array}$ & $\begin{array}{c}0.59 * * * \\
(0.02)\end{array}$ & $\begin{array}{c}0.57 * * * \\
(0.03)\end{array}$ \\
\hline & \multicolumn{6}{|c|}{ Difference Between Capital Output Elasticity and Capital Income Share } \\
\hline$\alpha-\mathrm{rK} / \mathrm{Y}$ & $\begin{array}{c}-0.15 * * * \\
(0.03)\end{array}$ & $\begin{array}{c}-0.05 * * * \\
(0.02)\end{array}$ & $\begin{array}{c}-0.05 * * * \\
(0.01)\end{array}$ & $\begin{array}{c}-0.16^{* * *} \\
(0.03)\end{array}$ & $\begin{array}{c}-0.05 * * * \\
(0.02)\end{array}$ & $\begin{array}{c}-0.05 * * * \\
(0.02)\end{array}$ \\
\hline Country FE & Yes & Yes & Yes & Yes & Yes & Yes \\
\hline Time FE & No & Yes & Yes & No & Yes & Yes \\
\hline Time FE $*$ Continent FE & No & No & Yes & No & No & Yes \\
\hline Observations & 496 & 496 & 496 & 496 & 496 & 496 \\
\hline Countries & 62 & 62 & 62 & 62 & 62 & 62 \\
\hline
\end{tabular}

Note: The method of estimation is least squares. Huber robust standard errors (shown in parentheses) are clustered at the country level. *Significantly different from zero at the 10 percent significance level, $* * 5$ percent significance level, ${ }^{* * *} 1$ percent significance level. 
Table 3. Rent Extraction by Capitalists

(Time Heterogeneity)

\begin{tabular}{|c|c|c|c|c|c|c|}
\hline \multirow[t]{2}{*}{ Dependent Variable is: } & \multicolumn{3}{|c|}{$\Delta \ln (\mathrm{Y} / \mathrm{L})$} & \multicolumn{3}{|c|}{$\Delta \ln (\mathrm{Y})$} \\
\hline & (1) & (2) & (3) & (4) & $(5)$ & (6) \\
\hline Indicator is: & $\begin{array}{l}\text { Post } 1980 \\
\text { Indicator }\end{array}$ & $\begin{array}{l}\text { Post } 1990 \\
\text { Indicator }\end{array}$ & $\begin{array}{l}\text { Post } 2000 \\
\text { Indicator }\end{array}$ & $\begin{array}{l}\text { Post } 1980 \\
\text { Indicator }\end{array}$ & $\begin{array}{l}\text { Post } 1990 \\
\text { Indicator }\end{array}$ & $\begin{array}{c}\text { Post } 2000 \\
\text { Indicator }\end{array}$ \\
\hline$\Delta \ln (\mathrm{K} / \mathrm{L})$ & $\begin{array}{c}0.42 * * * \\
(0.01)\end{array}$ & $\begin{array}{c}0.41 * * * \\
(0.02)\end{array}$ & $\begin{array}{c}0.42 * * * \\
(0.02)\end{array}$ & & & \\
\hline$\Delta \ln (\mathrm{K} / \mathrm{L}) *$ Indicator & $\begin{array}{l}-0.01 \\
(0.01)\end{array}$ & $\begin{array}{c}0.00 \\
(0.00)\end{array}$ & $\begin{array}{c}0.00 \\
(0.01)\end{array}$ & & & \\
\hline$\Delta \ln (\mathrm{K})$ & & & & $\begin{array}{c}0.41 * * * \\
(0.01)\end{array}$ & $\begin{array}{c}0.40 * * * \\
(0.02)\end{array}$ & $\begin{array}{c}0.40 * * * \\
(0.02)\end{array}$ \\
\hline$\Delta \ln (\mathrm{K}) *$ Indicator & & & & $\begin{array}{l}-0.01 \\
(0.01)\end{array}$ & $\begin{array}{c}0.00 \\
(0.00)\end{array}$ & $\begin{array}{c}0.00 \\
(0.00)\end{array}$ \\
\hline$\Delta \ln (\mathrm{L})$ & & & & $\begin{array}{c}0.49 * * * \\
(0.03)\end{array}$ & $\begin{array}{c}0.50 * * * \\
(0.03)\end{array}$ & $\begin{array}{c}0.50 * * * \\
(0.03)\end{array}$ \\
\hline \multirow[t]{2}{*}{$\Delta \ln (\mathrm{L}) *$ Indicator } & & & & $\begin{array}{c}0.01 \\
(0.01)\end{array}$ & $\begin{array}{l}-0.00 \\
(0.00)\end{array}$ & $\begin{array}{l}-0.00 \\
(0.01)\end{array}$ \\
\hline & \multicolumn{6}{|c|}{ Difference Between Capital Output Elasticity and Capital Income Share } \\
\hline$(\alpha-\mathrm{rK} / \mathrm{Y}) \mid$ Indicator $=1$ & $\begin{array}{c}-0.05 * * * \\
(0.02)\end{array}$ & $\begin{array}{c}-0.05 * * * \\
(0.02)\end{array}$ & $\begin{array}{c}-0.06^{* * *} \\
(0.02)\end{array}$ & $\begin{array}{c}-0.06^{* * *} * \\
(0.02)\end{array}$ & $\begin{array}{c}-0.07 * * * \\
(0.02)\end{array}$ & $\begin{array}{c}-0.07 * * * \\
(0.02)\end{array}$ \\
\hline$(\alpha-\mathrm{rK} / \mathrm{Y}) \mid$ Indicator $=0$ & $\begin{array}{l}-0.03 * \\
(0.02)\end{array}$ & $\begin{array}{c}-0.04 * * \\
(0.02)\end{array}$ & $\begin{array}{c}-0.04 * * * \\
(0.02)\end{array}$ & $\begin{array}{c}-0.04 * * \\
(0.02)\end{array}$ & $\begin{array}{c}-0.05 * * * \\
(0.02)\end{array}$ & $\begin{array}{c}-0.05 * * * \\
(0.02)\end{array}$ \\
\hline $\begin{array}{l}\{(\alpha-\mathrm{rK} / \mathrm{Y}) \mid \text { Indicator }=1\}- \\
\{(\alpha-\mathrm{rK} / \mathrm{Y}) \mid \text { Indicator }=0\}\end{array}$ & $\begin{array}{l}-0.02 * * * \\
(0.005)\end{array}$ & $\begin{array}{c}-0.01 * * * \\
(0.005)\end{array}$ & $\begin{array}{l}-0.02 * * * \\
(0.006)\end{array}$ & $\begin{array}{c}-0.02 * * * \\
(0.005)\end{array}$ & $\begin{array}{l}-0.01 * * * \\
(0.002)\end{array}$ & $\begin{array}{l}-0.02 * * * \\
(0.005)\end{array}$ \\
\hline Country FE & Yes & Yes & Yes & Yes & Yes & Yes \\
\hline Time FE & Yes & Yes & Yes & Yes & Yes & Yes \\
\hline Time FE * Continent FE & Yes & Yes & Yes & Yes & Yes & Yes \\
\hline Observations & 792 & 792 & 792 & 792 & 792 & 792 \\
\hline Countries & 111 & 111 & 111 & 111 & 111 & 111 \\
\hline
\end{tabular}

Note: The method of estimation is least squares. Huber robust standard errors (shown in parentheses) are clustered at the country level. *Significantly different from zero at the 10 percent significance level, ** 5 percent significance level, *** 1 percent significance level. 
Table 4. Rent Extraction by Capitalists

(Democracies vs. Non-Democracies)

\begin{tabular}{|c|c|c|c|c|}
\hline \multirow[t]{2}{*}{ Dependent Variable is: } & \multicolumn{2}{|c|}{$\Delta \ln (\mathrm{Y} / \mathrm{L})$} & \multicolumn{2}{|c|}{$\Delta \ln (Y)$} \\
\hline & $(1)$ & $(2)$ & (3) & (4) \\
\hline Indicator is: & $\begin{array}{l}\text { Democracy Indicator } \\
\text { (Based on Average } \\
\text { Polity2 Score) }\end{array}$ & $\begin{array}{l}\text { Democracy Indicator } \\
\text { (Based on Polity2 } \\
\text { Score Predicted by } \\
\text { Distance to Equator) }\end{array}$ & $\begin{array}{c}\text { Democracy Indicator } \\
\text { (Based on Average } \\
\text { Polity2 Score) }\end{array}$ & $\begin{array}{l}\text { Democracy Indicator } \\
\text { (Based on Polity2 } \\
\text { Score Predicted by } \\
\text { Distance to Equator) }\end{array}$ \\
\hline$\Delta \ln (\mathrm{K} / \mathrm{L})$ & $\begin{array}{c}0.42 * * * \\
(0.02)\end{array}$ & $\begin{array}{c}0.41 * * * \\
(0.02)\end{array}$ & & \\
\hline$\Delta \ln (\mathrm{K} / \mathrm{L}) *$ Indicator & $\begin{array}{l}-0.01 \\
(0.02)\end{array}$ & $\begin{array}{l}-0.01 \\
(0.02)\end{array}$ & & \\
\hline$\Delta \ln (\mathrm{K})$ & & & $\begin{array}{c}0.41 * * * \\
(0.02)\end{array}$ & $\begin{array}{c}0.41 * * * \\
(0.02)\end{array}$ \\
\hline$\Delta \ln (\mathrm{K}) *$ Indicator & & & $\begin{array}{l}-0.01 \\
(0.02)\end{array}$ & $\begin{array}{l}-0.01 \\
(0.02)\end{array}$ \\
\hline$\Delta \ln (\mathrm{L})$ & & & $\begin{array}{c}0.49 * * * \\
(0.03)\end{array}$ & $\begin{array}{c}0.50 * * * \\
(0.03)\end{array}$ \\
\hline$\Delta \ln (\mathrm{L}) *$ Indicator & & & $\begin{array}{c}0.03 \\
(0.05)\end{array}$ & $\begin{array}{c}0.06 \\
(0.04)\end{array}$ \\
\hline \multicolumn{5}{|c|}{ Difference Between Capital Output Elasticity and Capital Income Share } \\
\hline$(\alpha-\mathrm{rK} / \mathrm{Y}) \mid$ Indicator $=1$ & $\begin{array}{c}0.01 \\
(0.02)\end{array}$ & $\begin{array}{c}0.00 \\
(0.02)\end{array}$ & $\begin{array}{c}0.00 \\
(0.02)\end{array}$ & $\begin{array}{l}-0.01 \\
(0.02)\end{array}$ \\
\hline$(\alpha-\mathrm{rK} / \mathrm{Y}) \mid$ Indicator $=0$ & $\begin{array}{c}-0.08 * * * \\
(0.02)\end{array}$ & $\begin{array}{c}-0.06 * * * \\
(0.02)\end{array}$ & $\begin{array}{c}-0.09 * * * \\
(0.02)\end{array}$ & $\begin{array}{c}-0.07 * * * \\
(0.02)\end{array}$ \\
\hline $\begin{array}{l}\{(\alpha-\mathrm{rK} / \mathrm{Y}) \mid \text { Indicator }=1\}- \\
\{(\alpha-\mathrm{rK} / \mathrm{Y}) \mid \text { Indicator }=0\}\end{array}$ & $\begin{array}{l}0.09^{* * * *} \\
(0.02)\end{array}$ & $\begin{array}{l}0.06^{* * * *} \\
(0.02)\end{array}$ & $\begin{array}{c}0.09^{* * *} \\
(0.02)\end{array}$ & $\begin{array}{l}0.06^{* * * *} \\
(0.02)\end{array}$ \\
\hline Country FE & Yes & Yes & Yes & Yes \\
\hline Time FE & Yes & Yes & Yes & Yes \\
\hline Time FE * Continent FE & Yes & Yes & Yes & Yes \\
\hline Observations & 754 & 754 & 754 & 754 \\
\hline Countries & 106 & 106 & 106 & 106 \\
\hline
\end{tabular}

Note: The method of estimation is least squares. Huber robust standard errors (shown in parentheses) are clustered at the country level. *Significantly different from zero at the 10 percent significance level, $* * 5$ percent significance level, $* * * 1$ percent significance level. 
Table 5. Rent Extraction by Capitalists

(Democracies vs. Non-Democracies; Post-1990 Period)

\begin{tabular}{|c|c|c|c|c|}
\hline \multirow[t]{2}{*}{ Dependent Variable is: } & \multicolumn{2}{|c|}{$\Delta \ln (\mathrm{Y} / \mathrm{L})$} & \multicolumn{2}{|c|}{$\Delta \ln (\mathrm{Y})$} \\
\hline & (1) & $(2)$ & (3) & (4) \\
\hline Sample: & Democracies & Non-Democracies & Democracies & Non-Democracies \\
\hline$\Delta \ln (\mathrm{K} / \mathrm{L})$ & $\begin{array}{c}0.41 * * * \\
(0.02)\end{array}$ & $\begin{array}{c}0.41 * * * \\
(0.02)\end{array}$ & & \\
\hline$\Delta \ln (\mathrm{K})$ & & & $\begin{array}{c}0.39 * * * \\
(0.02)\end{array}$ & $\begin{array}{c}0.40 * * * \\
(0.02)\end{array}$ \\
\hline \multirow[t]{2}{*}{$\Delta \ln (\mathrm{L})$} & & & $\begin{array}{c}0.54 * * * \\
(0.04)\end{array}$ & $\begin{array}{c}0.51 * * * \\
(0.04)\end{array}$ \\
\hline & \multicolumn{4}{|c|}{ Difference Between Capital Output Elasticity and Capital Income Share } \\
\hline$\alpha-\mathrm{rK} / \mathrm{Y}$ & $\begin{array}{l}-0.00 \\
(0.02)\end{array}$ & $\begin{array}{c}-0.09 * * * \\
(0.02)\end{array}$ & $\begin{array}{l}-0.02 \\
(0.02)\end{array}$ & $\begin{array}{c}-0.09 * * * \\
(0.02)\end{array}$ \\
\hline Observations & 132 & 292 & 132 & 292 \\
\hline Countries & 33 & 73 & 33 & 73 \\
\hline Country FE & Yes & Yes & Yes & Yes \\
\hline Time FE & Yes & Yes & Yes & Yes \\
\hline Time FE $*$ Continent FE & Yes & Yes & Yes & Yes \\
\hline
\end{tabular}

Note: The method of estimation is least squares. Huber robust standard errors (shown in parentheses) are clustered at the country level. *Significantly different from zero at the 10 percent significance level, $* * 5$ percent significance level, $* * * 1$ percent significance level. 
Table 6. Rent Extraction by Capitalists

(Anocracies)

\begin{tabular}{|c|c|c|c|c|c|c|}
\hline \multirow[t]{2}{*}{ Dependent Variable is: } & \multicolumn{3}{|c|}{$\Delta \ln (\mathrm{Y} / \mathrm{L})$} & \multicolumn{3}{|c|}{$\Delta \ln (Y)$} \\
\hline & (1) & (2) & (3) & (4) & $(5)$ & (6) \\
\hline Time Period: & $1970-2010$ & $1980-2010$ & $1990-2010$ & $1970-2010$ & $1980-2010$ & $1990-2010$ \\
\hline$\Delta \ln (\mathrm{K} / \mathrm{L})$ & $\begin{array}{c}0.38 * * * \\
(0.02)\end{array}$ & $\begin{array}{c}0.38 * * * \\
(0.02)\end{array}$ & $\begin{array}{c}0.39 * * * \\
(0.02)\end{array}$ & & & \\
\hline$\Delta \ln (\mathrm{K})$ & & & & $\begin{array}{c}0.37 * * * \\
(0.02)\end{array}$ & $\begin{array}{c}0.37 * * * \\
(0.02)\end{array}$ & $\begin{array}{c}0.37 * * * \\
(0.02)\end{array}$ \\
\hline \multirow[t]{2}{*}{$\Delta \ln (\mathrm{L})$} & & & & $\begin{array}{c}0.53 * * * \\
(0.05)\end{array}$ & $\begin{array}{c}0.51 * * * \\
(0.07)\end{array}$ & $\begin{array}{c}0.50 * * * \\
(0.09)\end{array}$ \\
\hline & \multicolumn{6}{|c|}{ Difference Between Capital Output Elasticity and Capital Income Share } \\
\hline$\alpha-\mathrm{rK} / \mathrm{Y}$ & $\begin{array}{c}-0.09 * * * \\
(0.02)\end{array}$ & $\begin{array}{c}-0.10 * * * \\
(0.02)\end{array}$ & $\begin{array}{c}-0.09 * * * \\
(0.02)\end{array}$ & $\begin{array}{c}-0.10^{* * * *} \\
(0.02)\end{array}$ & $\begin{array}{c}-0.11 * * * \\
(0.02)\end{array}$ & $\begin{array}{c}-0.10 * * * \\
(0.02)\end{array}$ \\
\hline Observations & 398 & 324 & 228 & 398 & 324 & 228 \\
\hline Countries & 57 & 57 & 57 & 57 & 57 & 57 \\
\hline Country FE & Yes & Yes & Yes & Yes & Yes & Yes \\
\hline Time FE & Yes & Yes & Yes & Yes & Yes & Yes \\
\hline Time FE $*$ Continent FE & Yes & Yes & Yes & Yes & Yes & Yes \\
\hline
\end{tabular}

Note: The method of estimation is least squares. Huber robust standard errors (shown in parentheses) are clustered at the country level. *Significantly different from zero at the 10 percent significance level, $* * 5$ percent significance level, $* * * 1$ percent significance level. 
Table 7. Rent Extraction by Capitalists

(Autocracies)

\begin{tabular}{|c|c|c|c|c|c|c|}
\hline \multirow[t]{2}{*}{ Dependent Variable is: } & \multicolumn{3}{|c|}{$\Delta \ln (\mathrm{Y} / \mathrm{L})$} & \multicolumn{3}{|c|}{$\Delta \ln (Y)$} \\
\hline & (1) & (2) & (3) & (4) & $(5)$ & (6) \\
\hline Time Period: & $1970-2010$ & $1980-2010$ & $1990-2010$ & $1970-2010$ & $1980-2010$ & $1990-2010$ \\
\hline$\Delta \ln (\mathrm{K} / \mathrm{L})$ & $\begin{array}{c}0.49 * * * \\
(0.02)\end{array}$ & $\begin{array}{c}0.49 * * * \\
(0.03)\end{array}$ & $\begin{array}{c}0.48 * * * \\
(0.03)\end{array}$ & & & \\
\hline$\Delta \ln (\mathrm{K})$ & & & & $\begin{array}{c}0.48 * * * \\
(0.03)\end{array}$ & $\begin{array}{c}0.48 * * * \\
(0.03)\end{array}$ & $\begin{array}{c}0.47 * * * \\
(0.03)\end{array}$ \\
\hline \multirow[t]{2}{*}{$\Delta \ln (\mathrm{L})$} & & & & $\begin{array}{c}0.48 * * * \\
(0.04)\end{array}$ & $\begin{array}{c}0.47 * * * \\
(0.04)\end{array}$ & $\begin{array}{c}0.50 * * * \\
(0.03)\end{array}$ \\
\hline & \multicolumn{6}{|c|}{ Difference Between Capital Output Elasticity and Capital Income Share } \\
\hline$\alpha-\mathrm{rK} / \mathrm{Y}$ & $\begin{array}{c}-0.10 * * * \\
(0.03)\end{array}$ & $\begin{array}{c}-0.10 * * * \\
(0.03)\end{array}$ & $\begin{array}{c}-0.11 * * * \\
(0.04)\end{array}$ & $\begin{array}{c}-0.11 * * * \\
(0.02)\end{array}$ & $\begin{array}{c}-0.10 * * * \\
(0.03)\end{array}$ & $\begin{array}{c}-0.12 * * * \\
(0.03)\end{array}$ \\
\hline Observations & 120 & 94 & 61 & 120 & 94 & 64 \\
\hline Countries & 16 & 16 & 16 & 16 & 16 & 16 \\
\hline Country FE & Yes & Yes & Yes & Yes & Yes & Yes \\
\hline Time FE & Yes & Yes & Yes & Yes & Yes & Yes \\
\hline Time FE $*$ Continent FE & Yes & Yes & Yes & Yes & Yes & Yes \\
\hline
\end{tabular}

Note: The method of estimation is least squares. Huber robust standard errors (shown in parentheses) are clustered at the country level. *Significantly different from zero at the 10 percent significance level, $* * 5$ percent significance level, $* * * 1$ percent significance level. 
Appendix Table 1. List of Countries in Sample

\begin{tabular}{|c|c|c|c|}
\hline Argentina & Estonia & Lesotho & Saudi Arabia \\
\hline Armenia & Fiji & Lithuania & Senegal \\
\hline Australia & Finland & Luxembourg & Serbia \\
\hline Austria & France & Macao & Sierra Leone \\
\hline Bahrain & Gabon & Malaysia & Singapore \\
\hline Barbados & Germany & Malta & Slovak Republic \\
\hline Belgium & Greece & Mauritania & Slovenia \\
\hline Benin & Guatemala & Mauritius & South Africa \\
\hline Bolivia & Honduras & Mexico & Spain \\
\hline Botswana & Hong Kong & Moldova & Sri Lanka \\
\hline Brazil & Hungary & Mongolia & Swaziland \\
\hline Bulgaria & Iceland & Morocco & Sweden \\
\hline Burundi & India & Mozambique & Switzerland \\
\hline Cameroon & Indonesia & Namibia & Taiwan \\
\hline Canada & Iran & Netherlands & Tajikistan \\
\hline Central African Rep. & Iraq & New Zealand & Tanzania \\
\hline Chile & Ireland & Niger & Thailand \\
\hline China & Israel & Norway & Togo \\
\hline Colombia & Italy & Panama & Trinidad \& Tobago \\
\hline Costa Rica & Jamaica & Paraguay & Tunisia \\
\hline Cote d'Ivoire & Japan & Peru & Turkey \\
\hline Croatia & Jordan & Philippines & Ukraine \\
\hline Cyprus & Kazakhstan & Poland & United Kingdom \\
\hline Czech Republic & Kenya & Portugal & United States \\
\hline Denmark & Korea, Rep. of & Qatar & Uruguay \\
\hline Dominican Republic & Kuwait & Romania & Venezuela \\
\hline Ecuador & Kyrgyzstan & Russia & Zimbabwe \\
\hline Egypt & Latvia & Rwanda & \\
\hline
\end{tabular}




\section{Appendix Table 2. Description of Variables and Summary Statistics}

\begin{tabular}{llccc}
\hline Variable & \multicolumn{1}{c}{ Description } & Mean & Stdv. & Obs. \\
\hline$\Delta \ln (\mathrm{Y})$ & 5-Year change in natural logarithm of output-side PPP GDP. Source: PWT 8. & 0.18 & 0.19 & 792 \\
$\Delta \ln (\mathrm{K})$ & 5-Year change in natural logarithm of capital stock at PPP. Source: PWT 8. & 0.26 & 0.19 & 792 \\
$\Delta \ln (\mathrm{L})$ & 5-Year change in natural logarithm of number of workers. Source: PWT 8. & 0.10 & 0.10 & 792 \\
$\Delta \ln (\mathrm{Y} / \mathrm{L})$ & $\Delta \ln (\mathrm{Y})-\Delta \ln (\mathrm{L})$, see above. Source: PWT 8. & 0.08 & 0.19 & 792 \\
$\Delta \ln (\mathrm{K} / \mathrm{L})$ & $\Delta \ln (\mathrm{K})-\Delta \ln (\mathrm{L})$, see above. Source: PWT 8. & 0.16 & 0.18 & 792 \\
$\mathrm{rk} / \mathrm{Y}$ & Capital income share. Source: PWT 8. & 0.46 & 0.13 & 792 \\
\hline
\end{tabular}


Appendix Table 3. Im-Pesaran-Shin Panel Unit Root Test Results

\begin{tabular}{cccc}
\hline Variable (Levels) & p-value, H0:Unit Root & Variable (First Difference) & p-value, H0:Unit Root \\
$\ln (\mathrm{Y} / \mathrm{L})$ & 0.98 & $\Delta \ln (\mathrm{Y} / \mathrm{L})$ & 0.00 \\
$\ln (\mathrm{K} / \mathrm{L})$ & 1.00 & $\Delta \ln (\mathrm{K} / \mathrm{L})$ & 0.00 \\
$\ln (\mathrm{Y})$ & 0.94 & $\Delta \ln (\mathrm{Y})$ & 0.00 \\
$\ln (\mathrm{K})$ & 1.00 & $\Delta \ln (\mathrm{K})$ & 0.01 \\
$\ln (\mathrm{L})$ & 0.76 & $\Delta \ln (\mathrm{L})$ & 0.00 \\
\hline
\end{tabular}


Dependent Variable is: $\Delta \ln (\mathrm{Y} / \mathrm{L})$

\begin{tabular}{|c|c|c|c|}
\hline \multirow{3}{*}{$\Delta \ln (\mathrm{K} / \mathrm{L})$} & $(1)$ & $(2)$ & (3) \\
\hline & $\begin{array}{c}0.35^{* * *} \\
(0.02)\end{array}$ & $\begin{array}{c}0.41^{* * *} * \\
(0.02)\end{array}$ & $\begin{array}{c}0.41 * * * \\
(0.02)\end{array}$ \\
\hline & \multicolumn{3}{|c|}{ Difference Between Capital Output Elasticity and Capital Income Share } \\
\hline$\alpha-\mathrm{rK} / \mathrm{Y}$ & $\begin{array}{c}-0.12 * * * \\
(0.02)\end{array}$ & $\begin{array}{c}-0.06 * * * \\
(0.02)\end{array}$ & $\begin{array}{c}-0.06 * * * \\
(0.02)\end{array}$ \\
\hline Country FE & Yes & Yes & Yes \\
\hline Time FE & No & Yes & Yes \\
\hline Time FE $*$ Continent FE & No & No & Yes \\
\hline Observations & 455 & 455 & 455 \\
\hline Countries & 111 & 111 & 111 \\
\hline
\end{tabular}

Note: The method of estimation is least squares. Huber robust standard errors (shown in parentheses) are clustered at the country level. *Significantly different from zero at the 10 percent significance level, ** 5 percent significance level, $* * * 1$ percent significance level. 
Dependent Variable is:

$\underline{\ln (\mathrm{Y} / \mathrm{L})}$

(1)

(2)

(3)

$0.33^{* * * *}$

$0.39^{* * *}$

$0.40^{* * *}$

$\Delta \ln (\mathrm{K} / \mathrm{L})$

$(0.01)$

$(0.01)$

(0.02)

Difference Between Capital Output Elasticity and Capital Income Share

$\alpha-\mathrm{rK} / \mathrm{Y}$

$-0.14 * * *$

(0.01)

Yes

No

No

3962

111
$-0.08 * * *$

(0.02)

Yes

Yes

No

3962

111
$-0.08 * * *$

$(0.02)$

Yes

Yes

Yes

3962

111

Note: The method of estimation is least squares. Huber robust standard errors (shown in parentheses) are clustered at the country level. *Significantly different from zero at the 10 percent significance level, $* * 5$ percent significance level, $* * * 1$ percent significance level. 
Dependent Variable is: $\Delta \ln (\mathrm{Y})$

(1)

$\Delta \ln (\mathrm{K})$

$\Delta \ln (\mathrm{L})$

$\Delta(\mathrm{HC})$

Country FE

Time FE

Time FE * Continent FE

Observations

Countries
(2)

(3)
$0.34 * * *$

(0.02)

$0.48 * * *$

$(0.03)$

$0.22 * * *$

$(0.05)$
$0.41 * * *$

(0.01)

$0.52 * * *$

$(0.02)$

$0.22 * * *$

$(0.03)$
$0.40 * * *$

(0.02)

$0.50 * * *$

$(0.02)$

$0.24 * * *$

$(0.03)$

Difference Between Capital Output Elasticity and Capital Income Share
$-0.12 * * *$
$-0.05 * * *$
$-0.06 * * *$
(0.02)
$(0.01)$
$(0.02)$

$\begin{array}{lcc}\text { Yes } & \text { Yes } & \text { Yes } \\ \text { No } & \text { Yes } & \text { Yes } \\ \text { No } & \text { No } & \text { Yes } \\ 792 & 792 & 792 \\ 111 & 111 & 111\end{array}$

Note: The method of estimation is least squares. Huber robust standard errors (shown in parentheses) are clustered at the country level. *Significantly different from zero at the 10 percent significance level, $* * 5$ percent significance level, *** 1 percent significance level. 
Dependent Variable is:

$\Delta \ln (\mathrm{K} / \mathrm{L})$

$\Delta \ln (\mathrm{K} / \mathrm{L})^{*}$ Linear trend

$\Delta \ln (\mathrm{K})$

$\Delta \ln (\mathrm{K}) *$ Linear trend

$\Delta \ln (\mathrm{L})$

$\Delta \ln (\mathrm{L}) *$ Linear trend

$(\alpha-\mathrm{rK} / \mathrm{Y}) \mid \mathrm{Year}=1970$

$(\alpha-\mathrm{rK} / \mathrm{Y}) \mid$ Year $=2010$

$\{(\alpha-\mathrm{rK} / \mathrm{Y}) \mid$ Year=2010 $\}$ -

$\{(\alpha-\mathrm{rK} / \mathrm{Y}) \mid$ Year $=1970\}$

Country FE

Time FE

Time FE * Continent FE

Observations

Countries $\underline{\ln (\mathrm{Y} / \mathrm{L})}$

$\underline{\ln (Y)}$

(1)

(2)

$0.39 * * *$

(0.02)

0.00

(0.00)

$\begin{array}{cc} & 0.39^{* * * *} \\ & (0.03) \\ & 0.00 \\ & (0.00) \\ & 0.59^{* * *} \\ & (0.04) \\ & -0.01 \\ & (0.01) \\ -0.04 * * & -0.04 * \\ (0.02) & (0.02) \\ -0.07 * * * & -0.08^{* * *} \\ (0.01) & (0.02) \\ -0.04 * & -0.05^{* *} \\ (0.02) & (0.02) \\ \text { Yes } & \text { Yes } \\ \text { Yes } & \text { Yes } \\ \text { Yes } & \text { Yes } \\ 792 & 792 \\ 111 & 111\end{array}$

Note: The method of estimation is least squares. Huber robust standard errors (shown in parentheses) are clustered at the country level. *Significantly different from zero at the 10 percent significance level, ** 5 percent significance level, ${ }^{* * *} 1$ percent significance level. 